\title{
GAMBARAN HISTOLOGIK AORTA TIKUS WISTAR DENGAN DIET LEMAK BABI SETELAH PEMBERIAN EKSTRAK DAUN PEPAYA
}

\author{
${ }^{1}$ Friska W. F. Panjaitan \\ ${ }^{2}$ Marie M. Kaseke \\ ${ }^{2}$ George N. Tanudjaja
}

\author{
${ }^{1}$ Kandidat Skripsi Fakultas Kedokteran Universitas Sam Ratulangi Manado \\ ${ }^{2}$ Bagian Anatomi Histologi Fakultas Kedokteran Universitas Sam Ratulangi \\ Email: frizka_17@hotmail.com
}

\begin{abstract}
Papaya leaves contain several antioxidants (flavonoid, tanin, and vitamin C) which have antiatherogenic effects that may inhibit the progression of an atherosclerotic lesion. One of the risk factors causing atherosclerosis is the consumption of food containing highly saturated fatty acids e.g. lard. Low density lipoproteins (LDL) accumulate within the intima and then are oxidized (LDL-ox). This LDL-ox is ingested by macrophages, resulting in foamcell formation (early lesion of atherosclerosis). This study aimed to find out the histological features of the aorta of wistar rats having lard diets without the addition of the papaya leaf extract; having lard diets along with the papaya leaf extract; and having lard diets followed by papaya leaf extract. This was an experimental study on 16 wistar rats divided into 4 groups: group I without treatment (negative control group), group II lard diet for 14 days (positive control group), group III lard diet with papaya leaf extract for 14 days (treatment group I), and group IV lard diet for 14 days, and then followed by papaya leaf extract for 14 days (treatment group II). It was found that the aorta of group I showed adipose cells in the intima and media layers; group II and III showed foam cells in both layers; and group IV showed foam cells in fewer numbers than group II. Conclusion: The aorta histological features of wistar rats given lard diets for 14 days, with or without papaya leaf extract, showed foam cells in the intima and media layers. Papaya leaf extraxt added to lard diets had no effect on decreasing foam cells (no protective effect), meanwhile papaya leaf extract following lard diets showed a reduction of foam cells (therapeutic effect).
\end{abstract}

Keywords: papaya leaf, lard dietary, foam cells, wistar rat.

\begin{abstract}
Abstrak: Daun pepaya mengandung antioksidan (flavonoid, vitamin C) yang berefek antiaterogenik, sehingga diharapkan dapat menghambat perkembangan lesi aterosklerosis. Salah satu faktor risiko penyebab aterosklerosis yaitu makanan yang berkandungan tinggi asam lemak jenuh, antara lain lemak babi. Konsumsi lemak jenuh berlebihan dapat mengganggu fungsi sel endotel, sehingga lipoprotein berdensitas rendah (LDL) dapat masuk dan menjadi LDL teroksidasi (LDL-oks). Makrofag menangkap LDL-oks dan menjadi sel busa (lesi dini aterosklerosis). Penelitian ini bertujuan untuk mengetahui gambaran histologik aorta tikus wistar dengan diet lemak babi tanpa pemberian ekstrak daun pepaya, diet lemak babi bersamaan pemberian ekstrak daun pepaya, dan setelah diet lemak babi dilanjutkan pemberian ekstrak daun pepaya. Penelitian ini bersifat eksperimental. Subyek penelitian terdiri dari 16 ekor tikus wistar yang dibagi menjadi empat kelompok: kelompok I tanpa perlakuan (kelompok kontrol negatif); kelompok II dengan diet lemak babi selama 14 hari (kelompok kontrol positif); kelompok III dengan diet lemak babi serta pemberian ekstrak daun pepaya selama 14 hari (kelompok perlakuan I); dan kelompok IV dengan diet lemak babi selama 14 hari, dilanjutkan pemberian ekstrak daun pepaya selama 14 hari (kelompok perlakuan II). Hasil penelitian memperlihatkan gambaran histologi aorta kelompok I tampak perlemakan;
\end{abstract}


pada kelompok II terdapat sel-sel busa; pada kelompok III masih terdapat sel-sel busa; dan pada kelompok IV terdapat sel-sel busa, namun dalam jumlah yang lebih sedikit dibandingkan pada gambaran kelompok II. Simpulan: Tikus wistar dengan diet lemak babi selama 14 hari, baik dengan maupun tanpa ekstrak daun pepaya, memperlihatkan gambaran histologik adanya sel-sel busa pada tunika intima dan tunika media aorta. Pemberian ekstrak daun pepaya bersamaan dengan diet lemak babi tidak berefek menurunkan jumlah sel busa (tidak ada efek protektif) sedangkan pemberian ekstrak daun pepaya setelah diet lemak babi berefek mengurangi jumlah sel-sel busa yang terbentuk (efek terapi).

Kata kunci: daun pepaya, diet lemak babi, sel-sel busa, tikus wistar.

Pepaya (Carica papaya L.) merupakan tanaman buah famili Caricaceae yang berasal dari Amerika Tengah kemudian menyebar ke seluruh dunia, termasuk Indonesia. $^{1,2}$ Tanaman pepaya terkenal sebagai tanaman obat di berbagai belahan dunia. ${ }^{3}$ Manfaatnya sebagai obat alami bisa diperoleh dari hampir seluruh bagian tanaman pepaya. ${ }^{4}$ Masyarakat di Australia dan Indonesia telah memanfaatkan daun pepaya untuk mengobati kanker. ${ }^{5}$ Menurut penelitian Anibijuwon dan Udeze (2009), ${ }^{6}$ daun pepaya menunjukkan efek antibakteri sehingga dapat digunakan dalam penanganan gastroenteritis, uretritis, otitis media, dan luka infeksi. Daun pepaya mengandung metabolit sekunder alkaloid yang cukup banyak dibandingkan yang terdapat dalam buahnya. Selain itu, daunnya juga mengandung enzim papain sehingga sering digunakan untuk melumatkan daging. ${ }^{5}$ Daun pepaya juga mengandung karposid, saponin, serta anti-oksidan seperti vitamin C, tanin, dan flavonoid. ${ }^{7,8}$ Sebagai antioksidan, flavonoid dan tanin mempunyai efek yang menguntungkan terhadap fungsi endotel yaitu menurunkan oksidasi low density lipoprotein (LDL). ${ }^{9}$ Vitamin $\mathrm{C}$ juga mencegah oksidasi LDL terutama dengan menangkap radikal bebas. ${ }^{10}$

Oksidasi LDL akan menginduksi respon inflamasi pada endotel. Oksidasi kolesterol ini dapat memacu terjadinya proses aterosklerosis. ${ }^{9} \quad$ Aterosklerosis merupakan kelainan pembuluh darah arteri yang dapat terjadi oleh berbagai faktor risiko, salah satunya ialah makanan berkandungan lemak jenuh tinggi. Proses tersebut terutama mengenai arteri elastika seperti aorta, arteria karotis, dan arteria iliaka, serta arteri muskular besar dan sedang seperti arteri koronaria dan poplitea. ${ }^{11}$

Asupan kolesterol dan lemak jenuh yang tinggi pada makanan (antara lain: kuning telur, mentega, dan lemak hewani) dapat meningkatkan kadar kolesterol plasma. ${ }^{11}$ Lemak babi merupakan salah satu bahan makanan yang dapat meningkatkan kadar kolesterol. Lemak babi mengandung asam lemak jenuh ganda yang relatif lebih besar dari pada lemak ayam dan sapi. ${ }^{12}$ Konsumsi lemak jenuh berlebihan dapat meningkatkan kadar kolesterol total. ${ }^{9}$ Hiperkolesterolemia memicu adesi monosit dan meningkatkan pembentukan radikal bebas oksigen yang mendeaktivasi nitrik oksida sehingga mengganggu fungsi sel endotel. Hal ini menyebabkan permeabilitas endotel meningkat sehingga LDL masuk ke dalam intima. LDL akan teroksidasi (LDL-oks) dan monosit berubah menjadi makrofag yang kemudian memfagositosis LDL-oks sehingga membentuk sel busa. ${ }^{11}$

\section{METODE PENELITIAN}

Penelitian ini merupakan penelitian true-experiment dengan rancangan post-test randomized control group design. Penelitian ini dilakukan sejak minggu ke-1 bulan November sampai minggu ke-4 bulan Desember 2012 di Laboratorium Riset Penelitian Fakultas Kedokteran Universitas Sam Ratulangi dan Pusat Diagnostik Patologi Anatomi Manado.

Sebagai variabel bebas ialah pemberian ekstrak daun pepaya dan lemak babi, sedangkan sebagai variabel tergantung gambaran histologik aorta tikus wistar yang 
diberikan diet lemak babi tanpa, dengan, atau setelah pemberian ekstrak daun pepaya. Subjek penelitian ialah 16 ekor tikus wistar berusia 4-5 bulan dengan berat rata-rata 130 g. Penentuan subjek setiap kelompok dilakukan dengan simple random sampling.

Enam belas ekor tikus wistar diberi pakan pelet $\mathrm{AD} 2$ selama 2 hari, kemudian dibagi menjadi 4 kelompok (masingmasing terdiri dari 4 ekor): kelompok kontrol negatif (Kelompok I) yang diberi pakan pelet $\mathrm{AD} 2$ selama 14 hari; kelompok kontrol positif (Kelompok II) diberikan pelet lemak babi selama 14 hari; kelompok perlakuan I (Kelompok III) diberikan pelet lemak babi bersamaan dengan pemberian ekstrak daun pepaya $30 \mathrm{mg} /$ hari selama 14 hari; dan kelompok perlakuan II (Kelompok IV) diberikan pelet lemak babi pada hari ke-1 sampai dengan hari ke-14, dilanjutkan dengan pemberian ekstrak daun pepaya $30 \mathrm{mg}$ per hari pada hari ke-15 sampai dengan hari ke-28.

Lemak babi dicampur pelet AD2 dengan perbandingan 1:9. Proses ekstrak daun pepaya menggunakan metode maserasi dengan pelarut alkohol $96 \%$. Ekstrak daun pepaya diberikan per oral melalui NGT pediatrik nomor 5. Parameter yang digunakan ialah perubahan histologik berupa penimbunan lemak yang menghasilkan sel-sel busa sebagai prekusor terjadinya aterosklerosis. Sel busa diamati pada sediaan yang telah dipulas dengan pewarnaan hematoksilin eosin.

\section{HASIL PENELITIAN}

\section{Gambaran makroskopik aorta tikus wistar}

Gambaran makroskopik aorta kelompok I, II, III dan IV tidak menunjukkan terjadinya perubahan ataupun kelainan. Aorta tidak mengalami pengerasan dengan permukaan halus dan warna terlihat merah kecoklatan.

\section{Gambaran mikroskopik aorta tikus wistar}

Pada kelompok tikus wistar tanpa diet pelet lemak babi dan ekstrak daun pepaya, gambaran mikroskopik aorta tikus wistar menunjukkan lapisan aorta yang terdiri dari tiga lapisan yaitu tunika intima, tunika media dan tunika adventisia. Tampak selsel lemak pada tunika intima dan tunika media (Gambar 1).

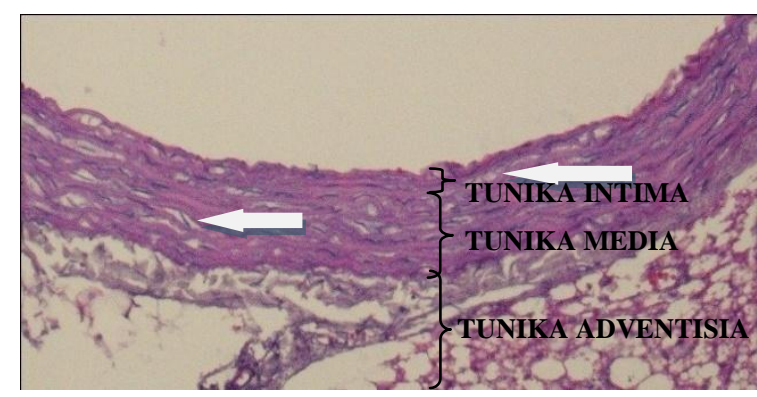

Gambar 1. Gambaran mikroskopik potongan melintang aorta tikus wistar tanpa diet pelet lemak babi dan ekstrak daun pepaya (kelompok I) dengan pembesaran $40 \times 10$. Terlihat adanya sel-sel lemak pada tunika intima dan media (anak panah).

Pada kelompok tikus wistar dengan diet pelet lemak babi selama 14 hari, gambaran mikroskopik aorta tikus wistar menunjukkan adanya sel-sel busa yang terlihat pada tunika intima dan tunika media (Gambar 2).

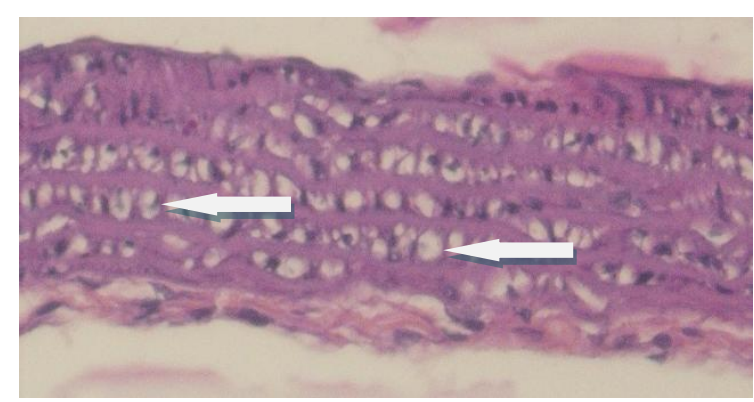

Gambar 2. Gambaran mikroskopik potongan melintang aorta tikus wistar dengan diet pelet lemak babi selama 14 hari (kelompok II) dengan pembesaran $20 \times 10$. Terlihat adanya sel-sel busa pada tunika intima dan tunika media (anak panah).

Pada kelompok tikus wistar dengan diet pelet lemak babi bersamaan dengan 
pemberian ekstrak daun pepaya selama 14 hari (Kelompok III) dan kelompok tikus wistar dengan diet pelet lemak babi selama 14 hari (IV), gambaran mikroskopik aorta menunjukkan masih banyak terlihat sel-sel busa pada tunika intima dan tunika media seperti pada kelompok (Gambar 3).

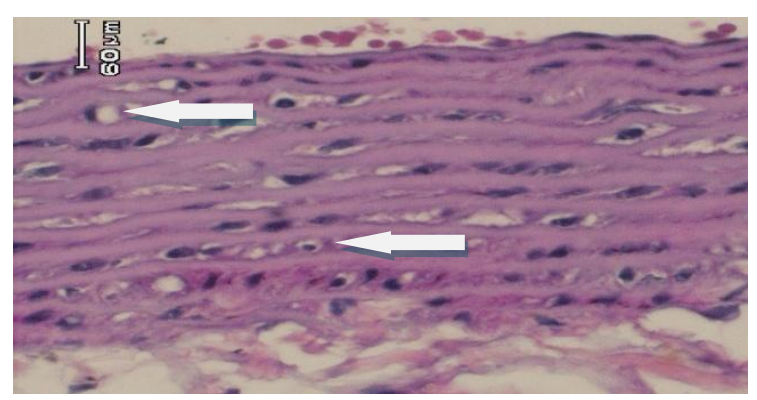

Gambar 3. Gambaran mikroskopik potongan melintang aorta tikus wistar dengan diet pelet lemak babi bersamaan dengan pemberian ekstrak daun pepaya selama 14 hari (kelompok III) dan dengan pembesaran $40 \times 10$. Masih terlihat banyak sel-sel busa pada tunika intima dan tunika media (anak panah).

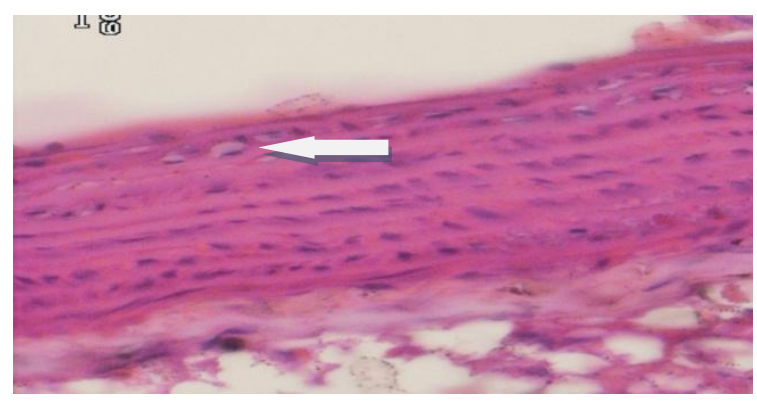

Gambar 4. Gambaran mikroskopik potongan melintang aorta tikus wistar dengan diet pelet lemak babi selama 14 hari dan dilanjutkan dengan pemberian ekstrak daun pepaya selama 14 hari (kelompok IV) dengan pembesaran $40 \mathrm{x}$ 10. Sel-sel busa masih terlihat tetapi dalam jumlah lebih sedikit (anak panah).

Pada kelompok tikus wistar dengan diet pelet lemak babi selama 14 hari dan dilanjutkan dengan pemberian ekstrak daun pepaya selama 14 hari, gambaran mikroskopik aorta tikus wistar menunjukkan masih terdapat sel-sel busa namun dalam jumlah yang lebih sedikit (Gambar 4) dibandingkan pada gambaran kelompok tikus wistar dengan diet pelet lemak babi selama 14 hari (Gambar 3).

Dari sampel penelitian yang berjumlah 16 ekor tikus wistar, sebanyak dua ekor dari kelompok IV mati selama perlangsungan penelitian.

\section{BAHASAN}

Dalam penelitian ini diamati pengaruh pemberian ekstrak daun pepaya (Carica papaya L.) terhadap gambaran histologik aorta tikus wistar dengan diet lemak babi. Pemberian ekstrak daun pepaya diharapkan dapat menyebabkan perubahan gambaran histologik aorta tikus wistar yang diberi diet lemak babi, yaitu berkurangnya sel-sel busa yang merupakan prekusor terjadinya aterosklerosis. Secara umum, hasil penelitian ini menunjukkan adanya perubahan gambaran histologik aorta tikus wistar pada kelompok perlakuan yang diberi diet lemak babi dan ekstrak daun pepaya.

Gambaran makroskopik aorta kelompok perlakuan tidak memperlihatkan perbedaan mencolok dibandingkan dengan kelompok kontrol negatif. Aorta tidak mengalami pengerasan, dengan permukaan halus dan warna terlihat merah kecoklatan. Hal ini mungkin disebabkan perlakuan yang diberikan tergolong singkat sehingga belum terbentuk lesi yang dapat dilihat secara makroskopik.

Dinding aorta tikus wistar terdiri dari tiga lapisan tunika konsentris. Lapisan terdalam ialah tunika intima, terdiri atas endotel dan jaringan ikat subendotel di bawahnya. Lapisan tengah ialah tunika media, terutama terdiri dari serat-serat elastin, dan juga sel-sel otot polos. Lapisan terluar ialah tunika adventisia, terutama terdiri atas serat-serat jaringan ikat. ${ }^{13}$ Pada kelompok tikus wistar tanpa diet pelet lemak babi dan ekstrak daun pepaya, gambaran mikroskopik aorta menunjukkan adanya sel-sel lemak pada tunika intima dan tunika media. Hal ini mungkin disebabkan kondisi awal tikus wistar telah mengalami hiperlipidemia sebelum menjadi sampel penelitian. Kelompok tikus wistar ini diperkirakan telah mengonsumsi lemak 
secara berlebihan sebelum digunakan dalam penelitian ini sehingga terjadi peningkatan kadar kolesterol LDL dalam darah. LDL secara normal bisa masuk dan keluar dinding arteri melalui endotel. Masuknya lipoprotein ke lapisan dalam dinding pembuluh darah meningkat seiring tingginya jumlah lipoprotein dalam plasma (hiperlipidemia), ukuran lipoprotein, dan tekanan darah (hipertensi). Peningkatan semua itu akan meningkatkan permeabilitas dinding pembuluh darah, sehingga lipoprotein dan ester kolesterol mengendap di dinding arteri. ${ }^{14}$ Kadar kolesterol LDL yang tinggi merupakan penjejas utama endotel. Paparan jejas pada endotel akan menginduksi lesi aterosklerotik. ${ }^{15}$

Pada gambaran mikroskopik aorta kelompok tikus wistar dengan diet pelet lemak babi selama 14 hari, pemeriksaan histopatologik memperlihatkan adanya selsel busa pada tunika intima sampai ke tunika media. Hal ini terjadi mungkin akibat konsumsi lemak babi secara berlebihan. Lemak babi mengandung asam lemak jenuh yang tinggi. Mengonsumsi lemak jenuh mengakibatkan kadar trigliserida, kolesterol total, dan LDL dalam darah meningkat (hiperlipidemia) dan kadar HDL menurun. ${ }^{9}$ Hiperlipidemia mengganggu fungsi endotel dengan meningkatkan produksi radikal bebas oksigen. Radikal ini menonaktifkan nitrik oksida, yaitu faktor endothelial-relaxing utama. Lipoprotein akan tertimbun dalam lapisan intima di tempat meningkatnya permeabilitas endotel. Pemajanan terhadap radikal bebas dalam sel endotel dinding arteri menyebabkan terjadinya oksidasi LDL, yang berperan dan mempercepat timbulnya plak ateromatosa. Hiperlipidemia memicu adesi monosit, migrasi sel otot polos subendotel, serta penimbunan lipid dalam makrofag dan sel-sel otot polos. Bila terpajan dengan LDL yang teroksidasi, makrofag menjadi sel busa yang beragregasi dalam lapisan intima, yang terlihat secara makroskopik sebagai bercak lemak. ${ }^{16}$

Pada kelompok tikus wistar dengan diet pelet lemak babi dan bersamaan dengan pemberian ekstrak daun pepaya selama 14 hari, gambaran mikroskopiknya menunjukkan masih terdapatnya sel-sel busa seperti pada kelompok tikus wistar dengan diet pelet lemak babi selama 14 hari. Hal ini disebabkan asupan pakan pada kelompok ini tinggi lemak, yang berakibat peningkatan kadar kolesterol. ${ }^{17}$ Pemberian ekstrak daun pepaya diharapkan dapat mencegah terbentuknya sel busa tetapi karena kelompok tersebut masih disertai dengan konsumsi asupan pakan tinggi lemak selama 14 hari dan pemberian dosis ekstrak daun pepaya yang kurang maka senyawa flavonoid dan vitamin $\mathrm{C}$ dalam ekstrak daun pepaya tidak dapat memberikan efek protektif, sehingga tetap terlihat banyak sel busa.

Kelompok tikus wistar dengan diet pelet lemak babi selama 14 hari dan dilanjutkan dengan pemberian ekstrak daun pepaya selama 14 hari, menunjukkan gambaran mikroskopik aorta tikus wistar masih terdapat sel-sel busa namun dalam jumlah yang lebih sedikit dibandingkan gambaran kelompok tikus wistar dengan diet pelet lemak babi selama 14 hari. Hal ini disebabkan kandungan antioksidan pada daun pepaya yaitu flavonoid, vitamin $\mathrm{C}$, dan juga serat yang dapat menurunkan tingkat peroksidasi lipid. Flavonoid dapat menghambat peroksidasi lipid dengan cara meredam radikal peroksil, sekaligus mengakhiri reaksi radikal. ${ }^{18}$ Vitamin $\mathrm{C}$ merupakan salah satu antioksidan yang memiliki sifat anti-aterogenik yang berfungsi untuk mengurangi oksidasi kolesterol. Vitamin $\mathrm{C}$ dapat membantu reaksi hidroksilasi dalam pembentukan asam empedu yang dapat meningkatkan ekskresi kolesterol dalam tubuh sehingga terjadi penurunan kadar kolesterol dalam darah. ${ }^{17}$ Serat mempunyai efek hipokolesterol karena serat dapat menyerap asam empedu dan kolesterol di dalam usus halus sehingga absorbsi kolesterol akan menurun. ${ }^{19}$ Pemberian ekstrak daun pepaya dapat mencegah terbentuknya sel busa, namun dalam penelitian ini kemungkinan dosis ekstrak daun pepaya yang diberikan belum optimal sehingga masih terbentuk sedikit sel busa pada kelompok tersebut. 


\section{SIMPULAN}

Dari hasil penelitian dapat disimpulkan bahwa tikus wistar dengan diet lemak babi selama 14 hari, baik dengan maupun tanpa ekstrak daun pepaya memperlihatkan gambaran histologik adanya sel-sel busa pada bagian tunika intima dan tunika media aorta tikus wistar. Pemberian ekstrak daun pepaya bersamaan dengan diet lemak babi tidak berefek menurunkan jumlah sel busa (tidak ada efek protektif) sedangkan pemberian ekstrak daun pepaya setelah diet lemak babi berefek mengurangi jumlah selsel busa yang terbentuk (efek terapi).

\section{UCAPAN TERIMA KASIH}

Ucapan terima kasih ditujukan kepada dr. Meilany Durry, M.Kes, SpPA dan dr. Sonny J. R. Kalangi, MBiomed, PA selaku penguji skripsi, dan semua pihak yang baik secara langsung maupun tidak langsung telah menumbuhkan idea dan gagasan pada penulis.

\section{DAFTAR PUSTAKA}

1. Melariri P, Campbell W, Etusim P, Smith P. Antiplasmodial properties and bioassay-guided fractionation of ethyl acetate extract from Carica papaya leaves. Journal of Parasitology Research [serial online]. 2011 [cited 2013 Aug 07]; 2011:1-7. Available from: http://www.hindawi.com/jour nals/jpr/2011/104954/.

2. Andarina NA. Gambaran Leukosit pada Mencit yang Diinfeksi Plasmodium berghei dan Diberi Infusa Daun Papaya (Carica papaya Linn.) [Skripsi]. Bogor: Fakultas Kedokteran Hewan Institut Pertanian Bogor; 2011.

3. Teixeira da Silva JA, Rashid Z, Tan Nhut D, Sivakumar D, Gera A, Souza Jr MT, et al. Papaya (Carica papaya L.) Biology and Biotechnology. Tree Forestry Sci Biotechnol. 2007;1:47-73.

4. Dalimartha S. Atlas Tumbuhan Obat Indonesia Jilid 6. Jakarta: Pustaka Bunda, 2009; p.121-3.

5. Sukardiman, Ekasari W, Hapsari PP. Aktivitas antikanker dan induksi apoptosis fraksi kloroform daun pepaya
(Carica papaya L.) terhadap Kultur Sel Kanker Mieloma. Media Kedokteran Hewan. 2006;22(2);125.

6. Anibijuwon LL, Udeze AO. Antimicrobial activity of Carica Papaya (Pawpaw Leaf) on some pathogenic organisms of clinical origin from South-Western Nigeria. Ethnobotanical Leaflets. 2009;13:857-8.

7. Krishna KL, Paridhavi M, Patel JA. Review on nutritional, medicinal and pharmacological, properties of papaya (Carica papaya Linn.). Natural Product Radiance. 2008;7(4):365.

8. Imaga NA, Gbenle GO, Okochi VI, Adenekan S, Emmanuel TD, Oyeniyi B, et al. Phytochemical and antioxidant nutrient constituents of Carica papaya and Parquetina nigrescens extracts. Academic Journals. 2010;5(16):2203-4.

9. Harini M, Astirin OP. Kadar kolesterol darah tikus putih (Rattus norvegicus) hiperkolesterolemik setelah perlakuan VCO. Bioteknologi. 2009;6(2):57-61.

10. Carr AC, Zhu BZ, Frei B. Potential Antiatherogenic Mechanisms of Ascorbate (Vitamin C) and $\alpha$ Tocopherol (Vitamin E). Journal of the American Heart Association. 2000;87(5):350.

11. Schoen FJ, Cotran RS. Pembuluh Darah. In: Kumar V, Cotran RS, Robbins SL, editors. Buku Ajar Patologi Volume 2 (Edisi 7). Jakarta: EGC, 2007; p.36978.

12. Hermanto S, Muawanah A. Profil dan Karakteristik Lemak Hewani (Ayam, Sapi dan Babi) Hasil Analisa FTIR dan GCMS. Jurnal Valensi. 2008;1(3):108.

13. Eroschenko VP. Atlas Histologi di Fiore dengan Korelasi Fungsional (Edisi 9). Jakarta: EGC, 2003.

14. Rastini EK, Widodo MA, Rohman MS. Pengaruh pemberian ekstrak buah mengkudu (Morinda citrifolia L.) terhadap aktivasi NF-K $\beta$ dan ekspresi protein (TNF- $\alpha$, ICAM-1) pada kultur sel endotel (HUVECs) dipapar OxLDL. J Exp Life Sci. 2010;1(1):48.

15. Prasetyo A, Sadhana U. Aspek seluler dan molekuler aterosklerosis. Media Medika Muda. Nodate [cited 2012 Nov 5]. Available from: http://eprints.undip.ac.id/1488/1/artikel _terkini.htm. 
S82 Jurnal Biomedik (JBM), Volume 5, Nomor 1, Suplemen, Maret 2013, hlm. S76-82

16. Brown CT. Penyakit aterosklerotik koroner. In: Price SA, Wilson LM. Patofisiologi: Konsep Klinis ProsesProses Penyakit Volume 1 (Edisi 6). Jakarta: EGC, 2005; p.585-8.

17. Dewi CK, Probosari E. Pengaruh pemberian buah pepaya (Carica papaya L) terhadap kadar kolesterol total pada tikus Sprague Dawley dengan hiperkolesterolemia. Journal of Nutrition
College. 2012;1(1):57-64.

18. Widowati W, Safitri R, Rumumpuk R, Siahaan M. Penapisan aktivitas superoksida dismutase pada berbagai tanaman. JKM. 2005;5(1):44.

19. Helmizar, Jalal F, Liputo I. Hubungan tingkat konsumsi antioksidan dengan profil lipid darah orang dewasa etnis Minangkabau di Kota Padang. Maj Kedokt Indon. 2010;60(8):362. 